\title{
Innovations in Education System: Management, Financial Regulation and Influence on the Pedagogical Process
}

\author{
Yuliya Zhuravlova ${ }^{1, *}$, Yaroslav Kichuk ${ }^{2}$, Olena Yakovenko ${ }^{3}$, Viktoriia Miziuk ${ }^{4}$, Serhii Yashchuk $^{5} \&$ Nina \\ Zhuravska $^{6}$ \\ ${ }^{1}$ Department of the State Service for the Quality of Education in the Odesa Region, Odesa, Ukraine \\ ${ }^{2}$ Department of Law and Social Work, Izmail State University of Humanities, Izmail, Ukraine \\ ${ }^{3}$ Department of Entrepreneurship and Tourism Management, Izmail State University of Humanities, Izmail, Ukraine \\ ${ }^{4}$ Department of Mathematics, Informatics and Information Activity, Izmail State University of Humanities, Izmail, \\ Ukraine \\ ${ }^{5}$ Foyer R D'accueil, Renovation Association, Bordeaux, France \\ ${ }^{6}$ Department of Management and Teaching Technologies, National University of Life and Environmental Sciences, \\ Kyiv, Ukraine \\ *Correspondence: Department of the State Service for the Quality of Education in the Odesa Region, 86, \\ Novoselskoho Str., 65045, Odesa, Ukraine
}

Received: December 7, 2021

Accepted: January 6, 2022 Online Published: January 17, 2022

doi:10.5430/jct.v11n1p163

URL: https://doi.org/10.5430/jct.v11n1p163

\begin{abstract}
The article aims to develop recommendations for improving universities' innovation management, their financial regulation and influence on the pedagogical process. The authors examined the essence of innovation and innovation in the education system, clearly presented their classification and methods of modernization, analyzed modern problems of management and financing of innovation in education. The authors contributed to managing innovation processes in the education system and improved the generalized model of the innovation process in the education system. As an improvement in the foundations of innovation management, the authors proposed the joint influence of the laws of the course of innovation processes, principles, stages, and functions of innovative processes that determine the direction of management activities at all stages. To improve financing by innovation, the authors empirically determined which tools are the most effective and efficient. The authors used the methods of expert assessments to present their proposals visually. At the same time, the authors emphasize the importance of using the synergistic effect here, too. The rest of the instruments will only enhance the effectiveness of the priority instrument for financing innovations in the education system. The systematic use of other tools is no less compelling. The proposed ways of improvement will allow universities to manage innovations and their financing more effectively.
\end{abstract}

Keywords: education, education system, innovations, financial regulation, synergy

\section{Introduction}

At the present stage of the development of society, significant changes are taking place in various spheres of human life, which significantly affect the education system. New socio-economic conditions have given rise to many problems, and the choice of solutions is associated with developing theoretical and methodological issues of education management in current conditions. Innovations in education are actually significant and systemically self-organizing innovations that arise based on a variety of initiatives and innovations that become promising for the evolution of education, have a positive effect on the development of all forms and methods of teaching (Prokopenko et al., 2018; Kichuk, 2019; Bondar et al., 2021).

The concept of "innovative activity" concerning the development of modern education can be considered as a purposeful transformation of the content of training and the organizational and technological foundations of the educational process, aimed at improving the quality of educational services, the competitiveness of educational institutions and their graduates, ensuring the comprehensive personal and professional development of students. 
Innovations in the education system are natural; their content, forms and methods of implementation depend both on the global problems of human development and on the socio-economic, legal, spiritual and political processes of reforming society (Prokopenko et al., 2018; Gumennykova et al., 2020; Mardonov \& Toshtemirova, 2020; Axmedov et al., 2021).

Innovations in education are a priority for states interested in systemic economic development, strengthening the role of science, improving the well-being of the population and reducing social tension (Bondar et al., 2020; Hornyak, 2021). It is obvious that stagnation in the teaching system is a negative phenomenon that negatively affects the state and society, leading to the accumulation of systemic problems at all levels of existence.

The study's relevance is beyond doubt since success lies in constant improvement. The crisis phenomena that are increasingly manifested in society, such as the current COVID-19 pandemic, are forcing educational institutions to introduce new technologies and radically change the toolkit (Ceballos et al., 2021; Nikou \& Maslov, 2021). The article aims to develop recommendations for improving universities' innovation management and financial regulation.

\section{Literature Review}

Innovation is a broad concept. In terms of education, this is the use of new technological and methodological research and the timely replacement of outdated standards.

Progress of innovative technologies in the educational process - improving the system and increasing the effectiveness in practice (Dayang et al., 2020; Hornyák, 2021).

Modernization methods include (Figure 1).

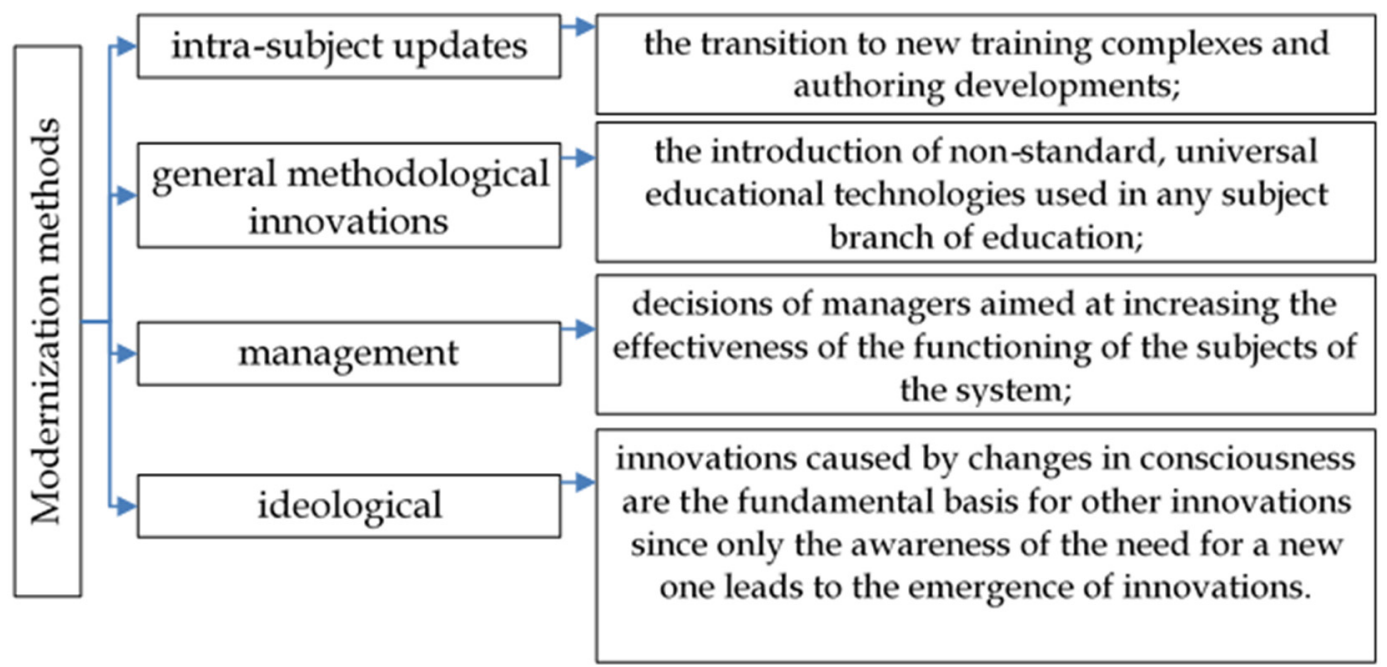

Figure 1. Methods of Modernization

The task of innovative technologies is a qualitative change in the subject's personality relative to the traditional system, which is possible with the use of programs that localize the problem of the pedagogical crisis. The main tasks of such programs are the formation of non-standard thinking and the full development of students' abilities.

\subsection{Challenges of Innovation in Education}

The problems of innovations in education begin already at the initial stage of development since each of the authors of innovations is not sure of the effectiveness of his plan. Any innovation is a risk without a guarantee

but attempts to improve innovative management in education continue.

Today, innovations are classified as (Adu-McVie et al., 2021; Ciołek et al., 2021; Okano et al., 2021):

Analog. The innovation is based on the classic method + private innovation principle.

Combined. Combining educational blocks to get a new approach. 
Retro innovative. It consists in attracting forgotten methods (gymnasium education, lyceums).

Essential. Implementation of previously unused innovations.

The authors consider the classification of innovations in terms of the most successful from the point of view of the research subject (Figure 2).

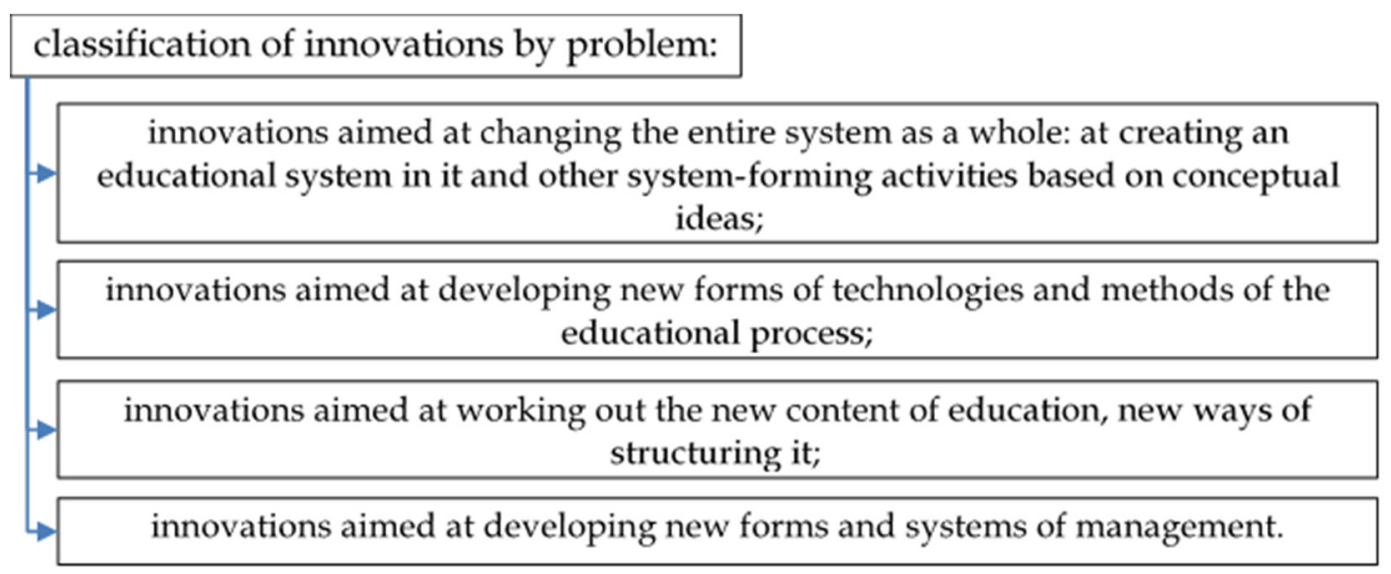

Figure 2. Classification of Innovation by Problem Circle

The essence of innovation in pedagogy lies in using effective teaching methods that meet the requirements of society and technology. In addition, innovations are required to relate to certain areas of distribution:

- educational;

- training;

- managerial;

- retraining.

Regulation of the process of introducing innovations is a multidisciplinary activity, including:

- $\quad$ setting and solving strategic tasks;

- $\quad$ risk monitoring;

- $\quad$ study of the structure and capabilities of an educational institution;

- formation of packages of innovative proposals, etc.

At the same time, the main directions of innovation management should be considered to develop a general strategy, material and technical support (financing) of the process and control over it.

Managing innovative processes in the regional education system reflects the sequence of stages of management activities and the achievement of specific results (Figure 3), which involves analytical and prognostic, target, design, organizational, implementation, expert evaluation, reflective stages.

The development of education is a purposeful process of its transition to higher quality levels, characterized by an increase in the efficiency of the activities of regional and territorial education management bodies, a developed structure of work with personnel, updating the activities of methodological services, activating innovative processes in the spheres of management, designing the content of education, developing learning technologies, etc. education. 


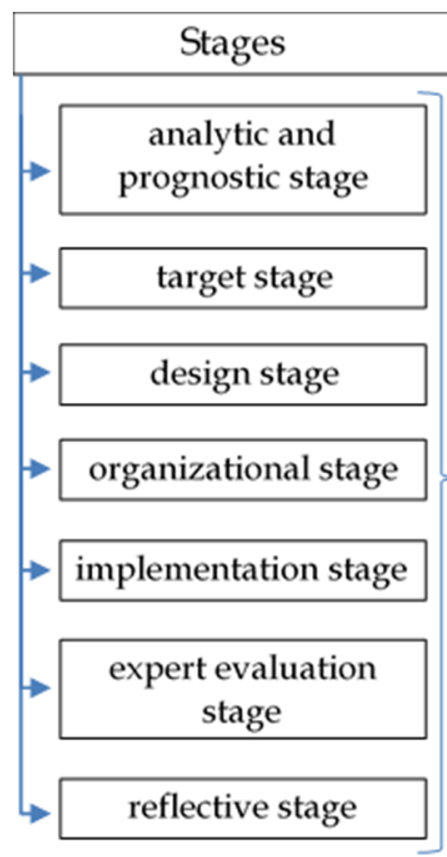

\begin{tabular}{|c|}
\hline Results \\
\hline $\begin{array}{l}\text { to define goals based on the analysis of the effects of socio- } \\
\text { economic, psychological, pedagogical and educational } \\
\text { expertise; }\end{array}$ \\
\hline $\begin{array}{l}\text { to develop programs for the development of the regional } \\
\text { education system in conjunction with programs for the } \\
\text { development of other spheres of the region; }\end{array}$ \\
\hline $\begin{array}{l}\text { to create conditions for the implementation of strategic and } \\
\text { tactical tasks of the development of the regional education } \\
\text { system, highlighting the preparation of pedagogical and } \\
\text { managerial personnel for innovations as an independent task } \\
\text { of the stage; }\end{array}$ \\
\hline $\begin{array}{l}\text { to develop regulatory documents defining the ways of } \\
\text { creating the resources necessary for the implementation of } \\
\text { innovations; }\end{array}$ \\
\hline to reflect on the ways to achieve the results obtained and \\
\hline
\end{tabular}

Figure 3. The Process of Managing Innovation Processes in the Regional Education System

According to many scientists (Shkitsa et al., 2020; Varzanova, 2020), who stood at the origins of the creation of infrastructure that supports the innovation activities of universities, modern universities should implement an entire innovation cycle associated with the creation of innovations. The main elements and stages of this cycle are shown in Figure 4.

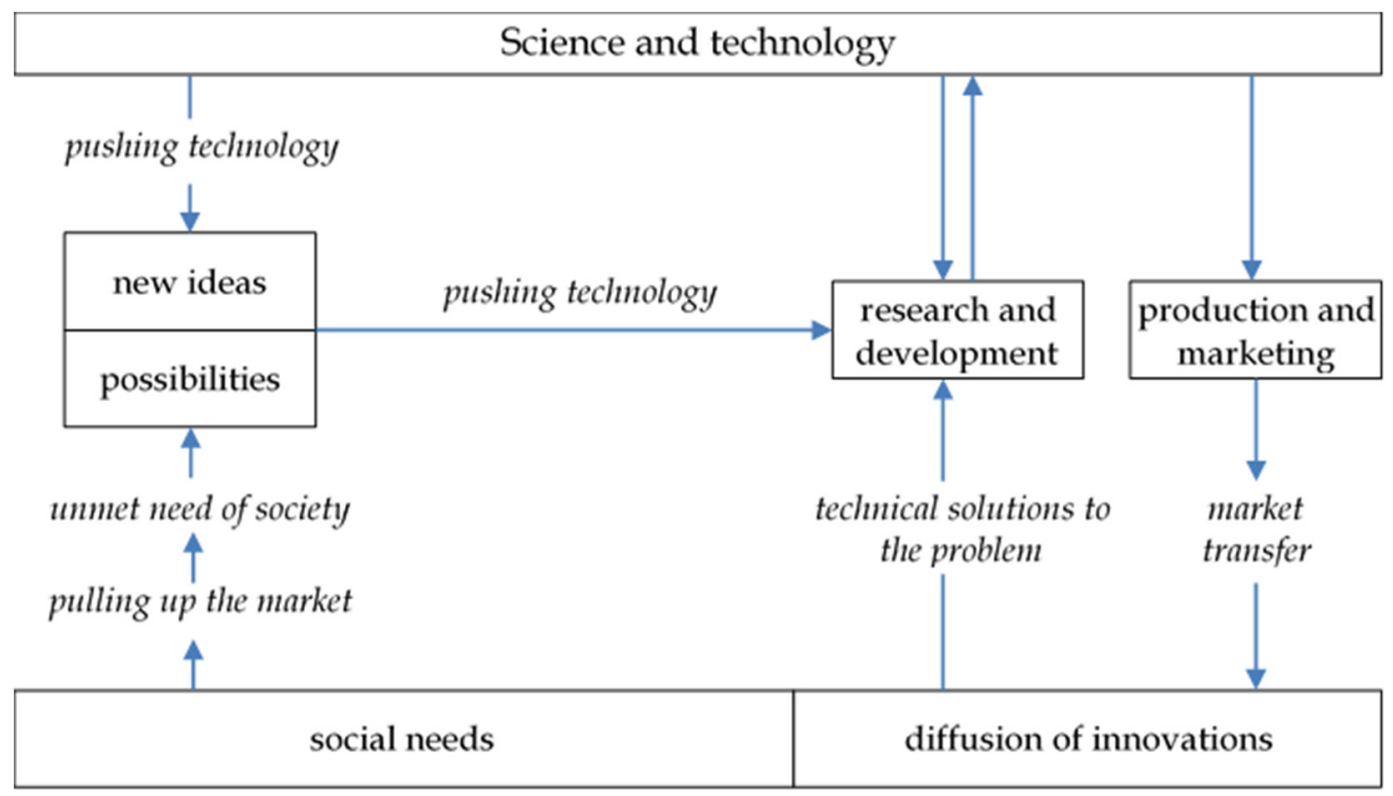

Figure 4. Generalized Model of the Innovation Process in Universities 
The condition for the development of education is the optimal management of innovation processes at all levels (Babaeva \& Grigorieva, 2020; Abdukadirovna, 2021). Therefore, the education manager should know and be able to:

- the essence of management activities;

- methods of developing programs for the development of educational institutions;

- to analyze and evaluate the innovative environment in an educational institution;

- to understand the nature, driving forces and structure of innovation processes;

- to master the methods of conducting pedagogical research of the organization of experimental work in the field of education;

- to set long-term goals and develop a development strategy;

- to organize the successful development of innovations;

- to predict and assess the consequences of decisions on the development of an educational institution.

When analyzing the innovation environment, the education manager needs to see the diversity of the existing structures of the innovation process in his developing institution. Thanks to this, it is possible to effectively manage changes, complete and further develop a particular structure's essential elements.

Funding for innovation. The university is financed from the following sources:

- $\quad$ state funding according to the norm per 1 student of the given contingent;

- provision of paid educational services;

- budget financing on a competitive basis (grants, government orders);

- implementation of the results of innovative activities;

- conclusion of business contracts with commercial organizations;

- the attraction of bank loans.

Each university approaches financing innovation differently within the framework of its autonomy (Bila et al., 2019; Zhuravlova et al., 2021). To date, there is no universal system for financing innovation and a system of indicators for the development of innovative activities of the university.

\section{Methods}

The authors used the methods of expert assessments to visually present their proposals and evaluated each proposed tool according to several criteria:

- ease of implementation - i.e. how fast and unbureaucratic a university can implement this tool;

- the speed of allocation of funds for innovation - i.e. how quickly the university can channel money for innovation;

- the amount of costs of the university - i.e. how much of its funds should allow the university to invest for the implementation of innovative projects;

- responsibility - i.e. accountability of the university for the results of financing innovations;

- the amount of funds - i.e. how large the amount will be at the disposal of the university to finance innovation;

- constancy - i.e. how often and for how long the university can use this tool.

The authors rated all instruments on a scale from 0 to 5 , where 5 is the best result. We distributed the importance weights in this way: ease of implementation -0.2 ; the speed of allocation of funds for innovation -0.25 ; the amount of university costs -0.18 ; responsibility -0.1 ; the amount of funds -0.12 ; constancy -0.15 (totally 1 ).

As a result, each instrument was assessed through the prism of the synergetic effect.

\section{Results}

\subsection{Improving the Management of Innovations in the Education System}

Innovation processes in education are a combination of procedures and tools that transform the idea of learning into a tangible innovation. The main elements of the process are the generation and use of innovations in combination with consistency, integrity and integrity. 


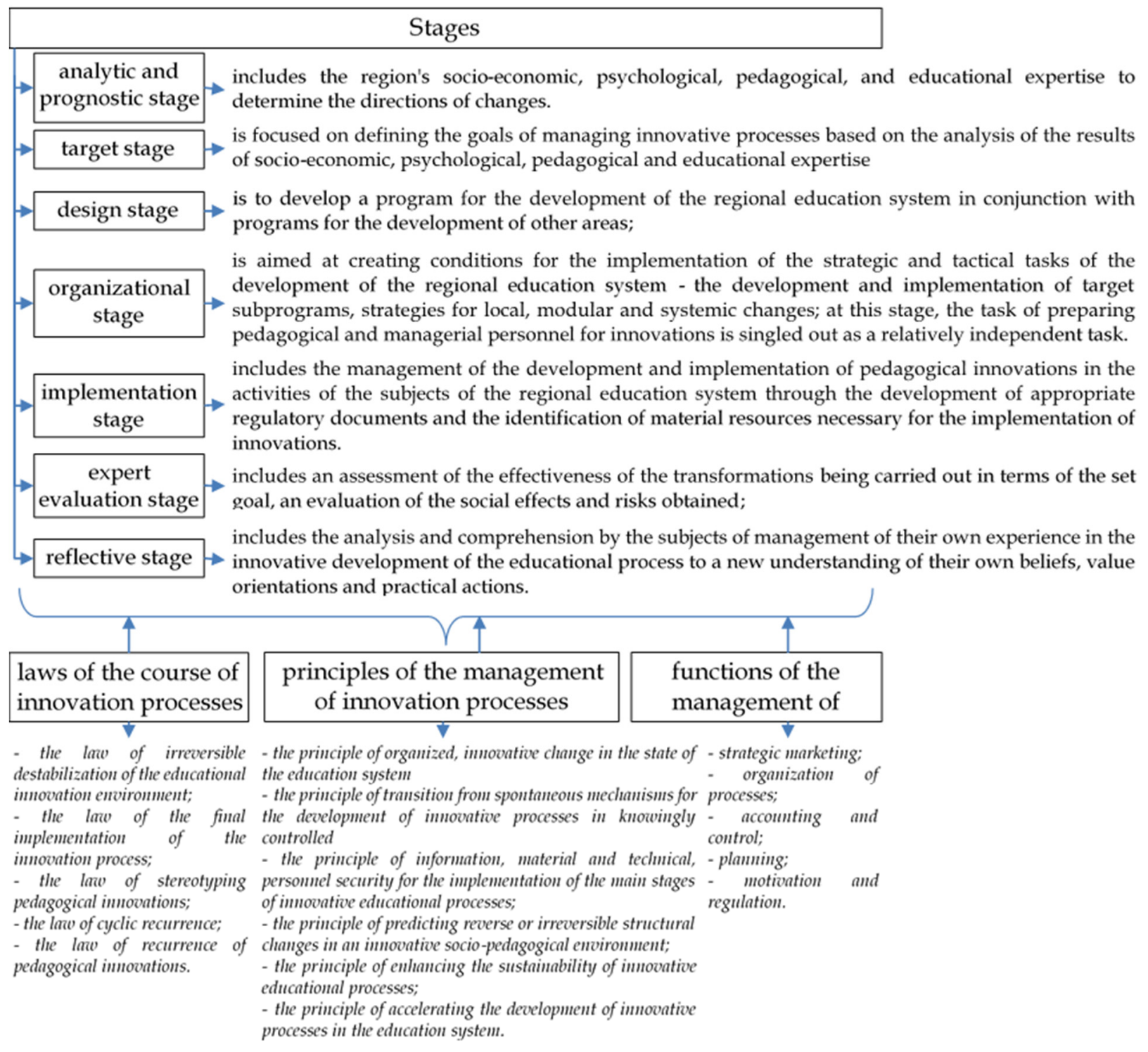

Figure 5. Generalized Model of the Innovation Process in Universities

Thus, as an improvement in the foundations of management, we consider the joint influence (Figure 5):

- laws of the course of innovation processes;

- principles of management of innovation processes, concretizing the implementation in practice of the laws of the flow of innovation processes;

- $\quad$ stages of management of innovation processes, revealing the sequence of management activities (basis - Figure 3). The selected stages are considered in the study as the basis for concretizing the stages of managing innovative processes in the education system;

- functions of the management of innovative processes that determine the direction of management activities at all stages.

The essence of the law of irreversible destabilization of the innovative pedagogical environment is that any innovative process in the education system inevitably introduces irreversible destructive changes in the innovative social and pedagogical environment in which it is carried out.

The law of the final implementation of the innovation process is associated with the fact that any innovation process, in the initial link of which there is an innovation, must sooner or later (spontaneously or deliberately) be 
implemented in mass practice.

The law of stereotyping of pedagogical innovations is as follows: any pedagogical innovation tends to become a stereotype of thinking and practical action.

The essence of the law of cyclic recurrence of pedagogical innovations lies in the repeated revival of innovations in new conditions.

The law of destabilization of the pedagogical innovation environment occupies a special place among the laws listed above since it (unlike others) operates at all stages of the innovation process.

The leading indicators of the productivity of the management of innovative processes in the education system:

- the quality of the education system (continuity, including during a pandemic and the transition to entire online teaching, openness, optimization of the network of educational institutions);

- the quality of the educational process (the quality of training of students, the professional competence of teachers, the comprehensive involvement of employers in the educational process, etc.);

- $\quad$ sustainability of social effects (reduction of offences, preservation of students' health, the satisfaction of the needs of various groups of the population in educational services, various educational institutions using various educational programs or their combinations; satisfaction of employers with graduates of educational institutions of various types and types, demand for educational institutions of all levels, provision material resources, etc.);

- the readiness of the management subjects of different levels for innovative transformations in the regional education system (the results of the implementation of educational programs and training of management and teaching staff).

\subsection{Improving Financial Regulation of Innovations in the Education System}

Each university has a relatively limited list of funding entities: own funds, stakeholder funds, government funding. At the same time, the possibilities of interaction are practically unlimited (Figure 6).

Let us consider in more detail the most important or least covered in the literature forms of financing innovation:

Own funds of the university. We offer two directions:

a) the formation of an investment fund, the financing of which can be carried out in 2 ways (see Figure 4). The purpose of creating such a fund is the purposeful accumulation of funds of the university, namely, to finance the university's innovations. More often than not, universities do not have such a fund. The introduction of innovations in education is postponed indefinitely, or an urgent search for funds from any reserves is underway. Such a fund will allow planning the development and implementation of innovations.

b) the creation of a small innovative enterprise (SIE). SIE is an organization that, in terms of the form of management and quantitative characteristics, refers to small business entities that, according to the charter, carry out innovative activities and enter into integration interaction with various market institutions (the state, large industrial organizations, research centres, investors). The purpose of creating such an SIE is to accumulate funds for financing innovations of the university from various sources, including through profit.

SIEs at universities can be created in the following main ways:

1) based on a scientific and educational organization with a complete merger of the authorized capital, that is, funds, equipment and other property that are in the operational management of the university can be contributed as a contribution to the official capital of the enterprise being created;

2) with the participation of employees of a scientific and educational organization, business representatives, a consulting organization;

3) the formation of an SIE with the involvement of representatives of higher education and large corporate (holding) structures;

4) the formation of an SIE with the involvement of representatives of higher education and foreign organizations.

SIEs abroad are effectively working subjects of the economy. The infrastructure created to provide comprehensive support for innovation includes technology incubators, technoparks, information networks, expert and consulting bureaus, patent services, financial support institutions, a developed stock market, a risk insurance system, etc. Such structures are combined into national and international innovation networks supporting small and medium-sized businesses in world practice. 


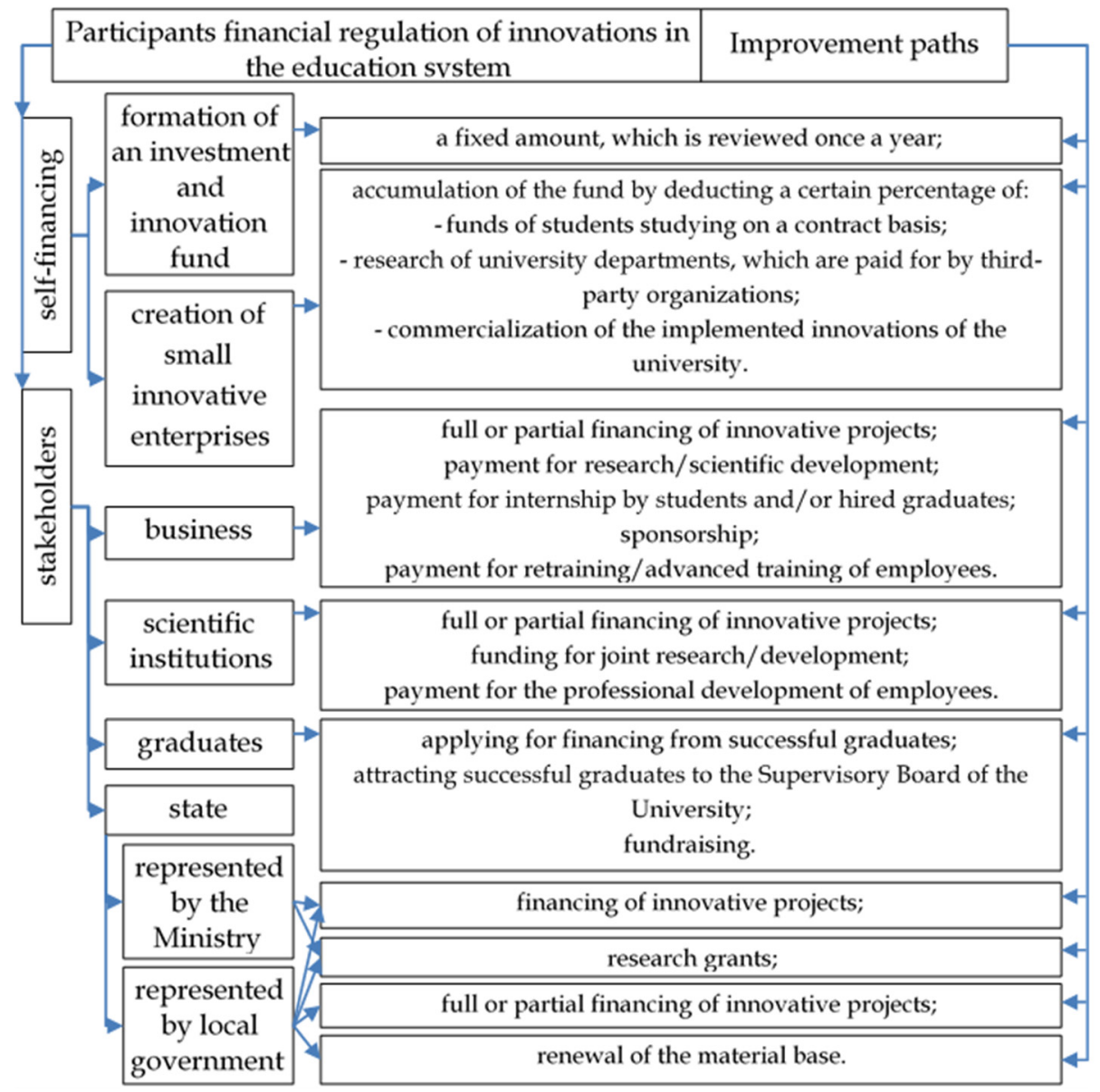

Figure 6. Stakeholders of Financial Regulation of Innovations in the Education System in the Context of the University

We consider this form one of the most promising areas for financing innovations in the education system.

For greater clarity, we evaluated each proposed tool (Table 1) according to the methods of expert assessments (Bashynska, 2015).

If we evaluate the tools simply by the sum of the criteria, then self-financing and cooperation with businesses and graduates turned out to be the most effective; however, the criteria cannot be equally equivalent for the university's management. Accordingly, given the importance of the criteria, in the end, the most effective tool turned out to be the formation of an innovation fund.

At the same time, we have already pointed out that the secret of effective and efficient innovation management lies in the synergy of tools. Thus, he believes that universities need to attract both graduates (in a short-term but effective way) and business. You should also not give up on joint projects with scientific institutions and apply for grants funded by the state. However, it is more efficient to accumulate the funds received in its investment and innovation fund. Moreover, work on financing innovations must be carried out systematically and planned, and not chaotically, at the onset of the need for financing innovations. 
Table 1. Evaluation of the Effectiveness of Financing Innovations in the Education System

\begin{tabular}{|c|c|c|c|c|c|c|c|c|c|}
\hline Instrument & 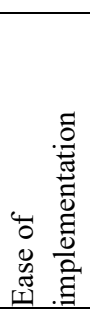 & 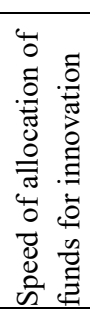 & 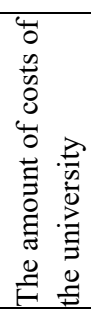 & 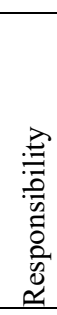 & 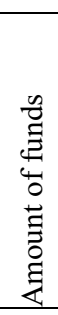 & 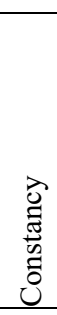 & 吾 & 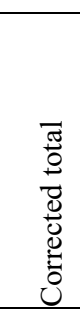 & 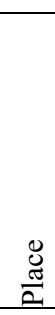 \\
\hline \multicolumn{10}{|c|}{ self-financing } \\
\hline formation of an investment and innovation fund & 5 & 5 & 1 & 5 & 1 & 5 & 22 & 3,80 & 1 \\
\hline creation of small innovative enterprises & 4 & 4 & 3 & 4 & 2 & 4 & 21 & 3,58 & 2 \\
\hline \multicolumn{10}{|c|}{ cooperation with stakeholders } \\
\hline business & 3 & 3 & 4 & 5 & 3 & 3 & 21 & 3,38 & 4 \\
\hline scientific institutions & 3 & 2 & 3 & 3 & 3 & 3 & 17 & 2,75 & 5 \\
\hline graduates & 4 & 3 & 5 & 5 & 3 & 1 & 21 & 3,46 & 3 \\
\hline Ministry & 1 & 1 & 5 & 1 & 5 & 2 & 15 & 2,35 & 7 \\
\hline local government & 2 & 2 & 4 & 2 & 4 & 3 & 17 & 2,75 & 5 \\
\hline
\end{tabular}

\section{Discussion}

Modern society is developing along the path of introducing new technologies. Regarding the pedagogical process, innovation means introducing something new into the goals, content, methods and forms of teaching and upbringing, the organization of joint activities of the teacher and the student. The key characteristics are novelty and practicality. Not all scientists note the positive impact of innovation on the educational process, some (Negi \& Chaudhary, 2021; Upadhyay, 2021; Vehteva et al., 2021). This is the most controversial point in the implementation of innovations. The authors believe that the education sector is one of the most innovative industries that largely determines the effectiveness of innovation in other industries, creating an innovative climate and the competitiveness of the economy as a whole. In other words, the nature, speed and efficiency of innovation processes in various sectors of the economy and spheres of activity significantly depend on the nature of the effectiveness of innovation in education.

The main social effect of innovation management in the education system is to ensure the quality of education in an open system of lifelong education that meets the educational needs of the population, progressive trends in socio-cultural and economic development, which allows us to consider the management of innovation processes in the regional education system as a mechanism for the formation of a "learning region".

\section{Conclusions}

The overall development and education of the individual following social needs is the primary task facing education. At the same time, the imperfection of the educational system complicates the development of new things, which significantly slows down the process. The introduction of innovative education methods is designed to improve learning outcomes.

In general, the innovation process in education transforms scientific knowledge (results of fundamental and applied research) and advanced pedagogical experience into pedagogical (educational) innovation.

The study showed that no matter what tools universities use to manage and finance innovations, their systematic and comprehensive use is more effective. The ways of improvement proposed in the article will allow universities to manage innovations and their financing more effectively. We believe that further promising research areas are developing indicators of the effectiveness and efficiency of innovation and investment activities of universities.

\section{References}

Abdukadirovna, M. (2021). Modern methods of effective management of innovation processes in the context of globalization. Asian Journal of Multidimensional Research, 10(9), 579-583. https://doi.org/10.5958/2278-4853.2021.00720.5

Adu-McVie, R., Yigitcanlar, T., Erol, I., \& Xia, B. (2021). Classifying innovation districts: Delphi validation of a 
$\begin{array}{llllll}\text { multidimensional } & \text { framework. } & \text { Land } & \text { Use }\end{array}$ https://doi.org/10.1016/j.landusepol.2021.105779.

Axmedov, M., Hojikarimova, G., Boybabayev, R., \& Safarova, G. (2021). Supporting innovative approaches in the education system. Academicia, 11(1), 38-41. https://doi.org/10.5958/2249-7137.2021.00001.X

Babaeva, A., \& Grigorieva, E. (2020). Principles of Innovation Processes Management. IOP Conference Series Materials Science and Engineering, 753(5), 052064. https://doi.org/10.1088/1757-899X/753/5/052064

Bashynska, I. (2015). Using the method of expert evaluation in economic calculations. Actual Problems of Economics, 7(169), 408-412.

Bila, O., Miziuk, V., Gumennykova, T., Kichuk, A., Sagan, O., \& Perminova, L. (2019). The use of modern interactive technologies in learning: correlation analysis of the results. International Journal of Innovative Technology and Exploring Engineering, 8(8), 3172-3175.

Bondar, I., Bachynska, N., Novalska, T., Kasian, V., Kuchnarov, V., \& Pylypiv, V. (2020). Analysis of the organization and features of the implementation of information technologies in the educational process of institutions of higher education. Systematic Reviews in Pharmacy, 11(11), 868-872.

Bondar, I., Humenchuk, A., Horban, Y., Honchar, L., \& Koshelieva, O. (2021). Conceptual and Innovative Approaches of Higher Education Institutions (Heis) to the Model of Training a Successful Specialist Formation During a Covid Pandemic. Journal of Management Information and Decision Sciences, 24(3), 1-8.

Ceballos, M., Vitale, T., \& Gordon, W. R. (2021). Remote continuity of learning and the COVID-19 pandemic: Educators' self-perceptions of preparedness. Journal of Pedagogical Sociology and Psychology, 3(2), 75-89. https://doi.org/10.33902/JPSP.2021271304

Ciołek, D., Golejewska, A., \& Abi-Yaghi, A. (2021). Regional Innovation Systems in Poland: How to classify them? Economy of Region, 17(3), 987-1003. https://doi.org/10.17059/ekon.reg.2021-3-19

Dayang, R., Khalip, M., \& Hamidah, Y. (2020). Innovation in Education. Journal of Educational Research and Indigenous Studies, 2(1), 1-11.

Gumennykova, T., Pankovets, V., Liapa, M., Miziuk, V., Gramatyk, N., \& Drahiieva, L. (2020). Applying instructional design methods to improve the effectiveness of blended-learning. International Journal of Management, 11(5), 31-42. https://doi.org/10.34218/IJM.11.5.2020.004

Hornyák, A. (2021). Innovation in education. The Hungarian Educational Research Journal, 11(3), 336-337. https://doi.org/10.1556/063.2021.00029

Kichuk, A. (2019). The health of the modern student: to the question of the mental and psychological components. Georgian medical news, 291, 85-89.

Mardonov, S., \& Toshtemirova, S. (2020). Classifying the educational system as an innovative approach. Theoretical \& Applied Science, 92(12), 180-182. https://doi.org/10.15863/TAS.2020.12.92.35

Negi, P., \& Chaudhary, A. (2021). Economic Globalization: Types and Its Positive \& Negative Impacts. International Journal of Applied Research, 7(S), 39-42. https://doi.org/10.22271/allresearch.2021.v7.i7Sa.8660

Nikou, S., \& Maslov, I. (2021). An analysis of students' perspectives on e-learning participation - the case of COVID-19 pandemic. International Journal of Information and Learning Technology, 38(3), 299-315. https://doi.org/10.1108/IJILT-12-2020-0220

Okano, M., Iamanaka, L., Ribeiro, R., Langhi, C., \& Fernandes, M. (2021). Classifying Social Enterprises Through Theoretical Typologies to Understand Social Innovation. International Journal of Business Administration, 12(6), 1. https://doi.org/10.1016/10.5430/ijba.v12n6p1

Prokopenko, O., Holmberg, R., \& Omelyanenko, V. (2018). Information and communication technologies support for the participation of universities in innovation networks (comparative study). Innovative Marketing, 14(3), 17-29. https://doi.org/10.21511/im.14(3).2018.03

Shkitsa, L., Kornuta, V., Kornuta, O., Bekish, I., \& Bui, V. (2020). Information Support of Design Innovation Activity of the Technical University. Management Systems in Production Engineering, 28(2), 127-132. https://doi.org/10.2478/mspe-2020-0019

Upadhyay, V. (2021). The negative impact of mobile phone on students and society. GFNPSS-International Journal of Multidisciplinary Research, 2(6), 665-668. https://doi.org/10.46376/IJMR/2.6.2021.665-668 
Varzanova, M. (2020). Supporting Innovative Activities of College Teachers. Izvestiya of Saratov University, 20(4), 449-453. https://doi.org/10.18500/1819-7671-2020-20-4-449-453

Vehteva, N., Nazarova, A., \& Surkova, E. (2021). Analysis and Modeling of the Negative Impact of Virtual Reality. Journal of Physics Conference Series, 2096(1), 012033. https://doi.org/10.1088/1742-6596/2096/1/012033

Zhuravlova, Y., Kichuk, N., Zhuravska, N., Yakovenko, O., Zhytnyk, V., \& Yashchuk, S. (2021). The Problem Field of Professional (Vocational) Education: Innovations and Ways to Improve. Studies of Applied Economics, 39(5). https://doi.org/10.25115/eea.v39i5.5274

\section{Copyrights}

Copyright for this article is retained by the author(s), with first publication rights granted to the journal.

This is an open-access article distributed under the terms and conditions of the Creative Commons Attribution license (http://creativecommons.org/licenses/by/4.0/). 